\title{
IDENTIFICATION AND USE OF INTANGIBLE RESOURCES IN MANAGING PRODUCTION ENTERPRISES IN THE AREA OF AVOIDING THREATS
}

\author{
Monika Osyra, Ewa Kempa \\ Czestochowa University of Technology
} Faculty of Management

\begin{abstract}
The paper analyzes the results of empirical research on intangible resources in production enterprises in the area of avoiding threats. The study concerned the identification and use of five types of intangible assets, namely knowledge, employee attitudes, formal and informal relations with the environment, and company image by medium and large enterprises in the manufacturing industry. The percentage distribution of the priority and the degree of use of a given intangible asset depending on the size of the enterprise were presented. The results of the research showed that employee attitudes are the dominant resource in the behavioral area of avoiding threats by enterprises. This resource was indicated as the most important both in general terms and separately by medium and large enterprises.
\end{abstract}

Keywords: resource approach, resource-based theory, intangible assets

DOI: $10.17512 /$ znpcz.2018.1.08

\section{Introduction}

Constant changes in the environment and the development of new technologies mean that enterprises are forced to react quickly to take advantage of opportunities and avoid threats. It is difficult to predict all threats that can occur inside and outside the company. Therefore, long-term strategies often did not allow for a reaction at the right moment. A remedy for this situation was the resource approach. A new look at the company management made it possible to quickly adapt the company's strategy to the turbulent environment (Krupski 2012, p. 238; Zakrzewska-Bielawska 2017, p. 181; Stańczyk-Hugiet 2013, p. 115) in this way avoiding or mitigating the effects of the threat. The increasingly popular resource approach has become, over time, a well-established theory in management sciences. The resource-based theory placing great emphasis on intangible assets changed the assessment of the company's value (Barney, Ketchen Jr., Wright 2011, p. 1303). The value of the enterprise was initially identified only with material goods and economic value, and with time it expanded into non-material goods as well as social and ecological aspects (Skowron-Grabowska 2013, p. 10; Potocan, Szkutnik, Nedelko 2017, p. 96; Pabian 2015, p. 8-9). Currently, the market value of the enterprise is mainly the share of intangible assets (Bombiak 2017, p. 317; Mazur 2017, p. 182). Intangible assets allow enterprises to respond flexibly and at the right time to the changes in the environment but require the proper use and 
management (Kuraś, Łęgowik-Świącik, Stępień 2016, p. 186). The management of intangible assets should be pragmatic, i.e., oriented towards their usefulness, efficiency and the provision of added value (Ziółkowska 2012, p. 157). That is why it is important for the company to have the resources of appropriate quality and market specificity useful for the implementation of specific processes (Matejun, Motyka 2016, p. 56-57; Daron 2017, p. 99). Unfortunately, the problem is that thera are no uniform patterns for examining intangible resources, which may be the reason for making some critical remarks regarding the resource theory (Czakon 2010, p. 19).

The aim of the paper is to identify and examine the use of selected intangible resources, namely knowledge, employee attitudes, formalized and informal relationships with the environment, and company image by medium and large enterprises in the manufacturing industry. This paper presents the results of the analysis carried out with the proprietary method developed in the course of research on the use of intangible assets by medium-sized and large-scale enterprises in the manufacturing industry. In this study, the authors focused on one of the behavioral areas of companies, i.e., avoiding threats.

\section{Enterprise intangible resources}

The concept of intangible resources is very broad and includes many types of values, relationships, competences, abilities, and skills of intangible nature. It is very difficult, if not impossible, to define intangible assets completely. In literature, there are up to 186 types of resources (Molloy et al. 2011, p. 1498). Another problem is the lack of consistent terminology and classification. Despite this nomenclature disorder, certain features characteristic of intangible resources can be mentioned (Niemczyk 2015, p. 18). Certainly, these are the features proposed for the first time by J.B. Barney (Barney 1991, p. 199-120), namely, valence, scarcity, difficulty in imitation and imitation which are the basis of the company's competitive advantage. Also, intangible resources are characterized by the possibility of using them simultaneously in various ways, by the accumulation method, enrichment in the use process and the way they are used by people (Głuszek 2004, p. 63). The basic differences between tangible and intangible assets are presented in Table 1.

Table 1. Comparison of tangible and intangible assets

\begin{tabular}{|l|l|l|}
\hline $\begin{array}{l}\text { 1. Place in the } \\
\text { accounting system }\end{array}$ & \multicolumn{1}{|c|}{ Tangible assets } & \multicolumn{1}{c|}{ Intangible assets } \\
\hline $\begin{array}{l}\text { 2. Availability and } \\
\text { mobility }\end{array}$ & $\begin{array}{l}\text { Using them by one group pre- } \\
\text { vents simultaneous use by } \\
\text { others. Immobile (land) or with } \\
\text { limited mobility (high transport } \\
\text { costs) }\end{array}$ & $\begin{array}{l}\text { Widely available and easy } \\
\text { to sell. Using them by one } \\
\text { group does not prevent } \\
\text { them from being used by } \\
\text { others. Rare and difficult to } \\
\text { copy. They are not entirely } \\
\text { owned by the company }\end{array}$ \\
\hline
\end{tabular}




\begin{tabular}{|l|l|l|}
\hline $\begin{array}{l}\text { 3. The rate of } \\
\text { depreciation }\end{array}$ & Depreciated over time & $\begin{array}{l}\text { They gain value if used } \\
\text { properly }\end{array}$ \\
\hline 4. Consumption & $\begin{array}{l}\text { Their value decreases with use } \\
\text { (depreciation) }\end{array}$ & $\begin{array}{l}\text { Their value increases with } \\
\text { usage (e.g., knowledge) }\end{array}$ \\
\hline 5. Protection & $\begin{array}{l}\text { Full protection by property } \\
\text { rights }\end{array}$ & $\begin{array}{l}\text { Limited legal regulations, } \\
\text { difficulties in enforcement }\end{array}$ \\
\hline
\end{tabular}

Source: (Bombiak 2017, p. 319)

The above comparison shows the unquestionable advantage of intangible resources over tangible ones regarding accessibility and mobility, the degree of depreciation and wear/consumption. Definitely, the weaker sides of intangible assets are issues related to their valuation and accounting as well as problems with limited legal protection. Of course, it must be remembered that intangible assets are also subject to wear in the event of improper management, time passing or sudden changes in circumstances. It is the case when knowledge, skills and professional experience laboriously acquired become scarce or not useful due to technological progress (Jamka 2011, p. 145). Moreover, because intangible assets are largely based on the human factor, they are also subject to biological depreciation (Makowski 2000, p. 11-12). That is why it is so important to properly manage intangible assets so that in the future they contribute to the development of competences that give the company a sustainable competitive advantage. For this to happen, however, it is necessary to identify key resources for a given company and strive to maximize their use. In relation to the above, the authors of the article conducted empirical research on the use of intangible resources. Because of the multitude of resources, five types of intangible assets were selected for the needs of the research, namely:

- knowledge, general skills, and skills of employees,

- employee attitudes - including availability, loyalty, creativity, diligence, etc.,

- relations established with the environment, i.e., the type of intelligent document, certificates, patents, and consents,

- informal relations with the environment, i.e., relations such as personal contacts, connections, sympathies, loyalty, etc.,

- company image - including trademarks, company's reputation, activity record.

\section{Research methodology}

The research was conducted among the representatives of top management of 60 medium and large production industry entities. They were MBA students at the University of Wrocław. The task of the respondents was to indicate the rank of a given resource and determine the degree of use of resources in several areas of company's behavior. This article presents the results of research on the selected area of the company's activity, i.e., avoiding threats.

Table 2 presents the survey that the participants of the study had to complete. 
Table 2. An example of a survey completed by MBA students at the University of Wroclaw, representing the top management of medium and large production enterprises

\begin{tabular}{|c|c|c|}
\hline The type of intangible asset & $\begin{array}{l}\text { Number the resources } \\
(1,2,3,4,5) \text { according } \\
\text { to their importance as } \\
\text { part of the hazard } \\
\text { avoidance level } \\
\text { (1 - least important, } \\
5 \text { - most important). } \\
\text { Fill in the gaps with the } \\
\text { appropriate number of } \\
\text { the scale }\end{array}$ & $\begin{array}{l}\text { Evaluate the degree of use } \\
\text { of a given resource in a } \\
\text { company within the strategic } \\
\text { level in a scale between } 1 \\
\text { and } 10, \text { where } 1 \text { means the } \\
\text { minimum and } 10 \text { maximum } \\
\text { use of the resource. } \\
\text { Highlight the correct number }\end{array}$ \\
\hline $\begin{array}{l}\text { Knowledge, skills, and } \\
\text { talents of employees }\end{array}$ & $\cdots \cdots$ & 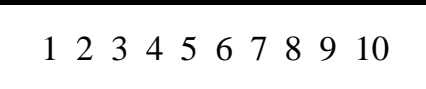 \\
\hline $\begin{array}{l}\text { Attitudes and employee } \\
\text { behavior (e.g. loyal- } \\
\text { ty,availability, etc.) }\end{array}$ & ..... & $\begin{array}{llllllllll}12 & 2 & 4 & 5 & 6 & 7 & 8 & 9 & 10\end{array}$ \\
\hline $\begin{array}{l}\text { Formal relations with the } \\
\text { environment (eg contracts, } \\
\text { concessions, certificates) }\end{array}$ & ..... & 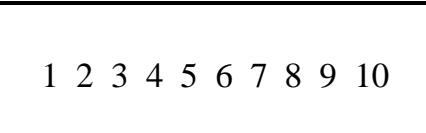 \\
\hline $\begin{array}{l}\text { Informal relations with the } \\
\text { environment } \\
\text { (e.g., resulting from } \\
\text { knowledge, trust, loyalty) }\end{array}$ & & $\begin{array}{llllllllll}12 & 3 & 4 & 5 & 6 & 7 & 8 & 9 & 10\end{array}$ \\
\hline $\begin{array}{l}\text { Company image } \\
\text { (trademarks, history, } \\
\text { reputation) }\end{array}$ & . & 1234566789610 \\
\hline
\end{tabular}

Source: (Krupski, Osyra 2013, p. 19-20)

The task of the respondents was to evaluate on the basis of their knowledge and professional experience:

- the importance (significance) of a given type of intangible assets, in a conventional scale from 1 to 5 ( 1 - the least important resource, 5 - the most important resource) and

- the degree of use of a given resource in shaping a given area in a conventional scale from 1 to $10(10$ - means the maximum use of the resource and 1 - means the minimal use of this resource).

\section{Analysis of the test results}

The first research results presented concern priority (importance) of intangible resources. Later, the level of utilization of particular resources in production enterprises in general and in terms of the company size (medium and large enterprises) will be presented. 
Figure 1 shows the percentage distribution of first-class intangible assets in the manufacturing industry in the area of threat avoidance.
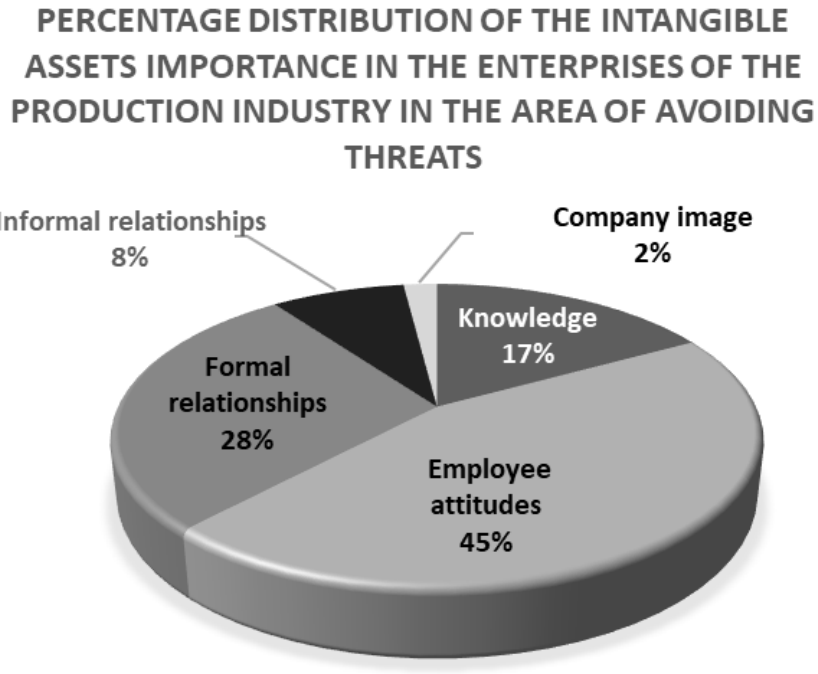

Figure 1. Percentage distribution of the importance of intangible assets in the production industry enterprises in the area of threat avoidance

Source: Own study based on the conducted research

Figure 1 shows that the most important resource in this behavioral area of the company turned out to be employee attitudes. As many as $45 \%$ of the respondents considered this resource as the most important in avoiding threats. Over one-fourth of the participants identified formal relationships as the most important (28\%). Knowledge received $17 \%$ of all responses, which gives it the third position. On the other hand, the most rarely indicated resources in the area of hazard avoidance were informal relationships (8\%) and company image (2\%).

The results of the percentage distribution of the primary distribution of intangible assets broken down into medium-sized and large enterprises in Table 3 show the difference in the assessment of the importance of a given resource depending on the size of the enterprise.

Table 3. Percentage distribution of the priority of a given intangible asset in medium-sized and large enterprises in the area of threat avoidance

\begin{tabular}{|l|c|c|}
\hline Resource & Medium enterprises & Large enterprises \\
\hline Knowledge & $10 \%$ & $18 \%$ \\
\hline Employee attitudes & $\mathbf{6 0 \%}$ & $\mathbf{4 2 \%}$ \\
\hline Formal relationships & $0 \%$ & $34 \%$ \\
\hline Informal relationships & $30 \%$ & $4 \%$ \\
\hline Company image & $0 \%$ & $2 \%$ \\
\hline
\end{tabular}

Source: Own study based on the conducted research 
In both medium and large enterprises, the most important resource in the area of avoiding threats was employee attitudes $-42 \%$ and $60 \%$, respectively. The second place in medium-sized enterprises is occupied by informal relationships (30\%) and in large enterprises by formal relationships (34\%). The third place in both cases was taken by knowledge. The image of the company is marginal regardless of the size of the company.

The level of use of intangible resources in the area of threat avoidance in manufacturing enterprises is shown in Figure 2.

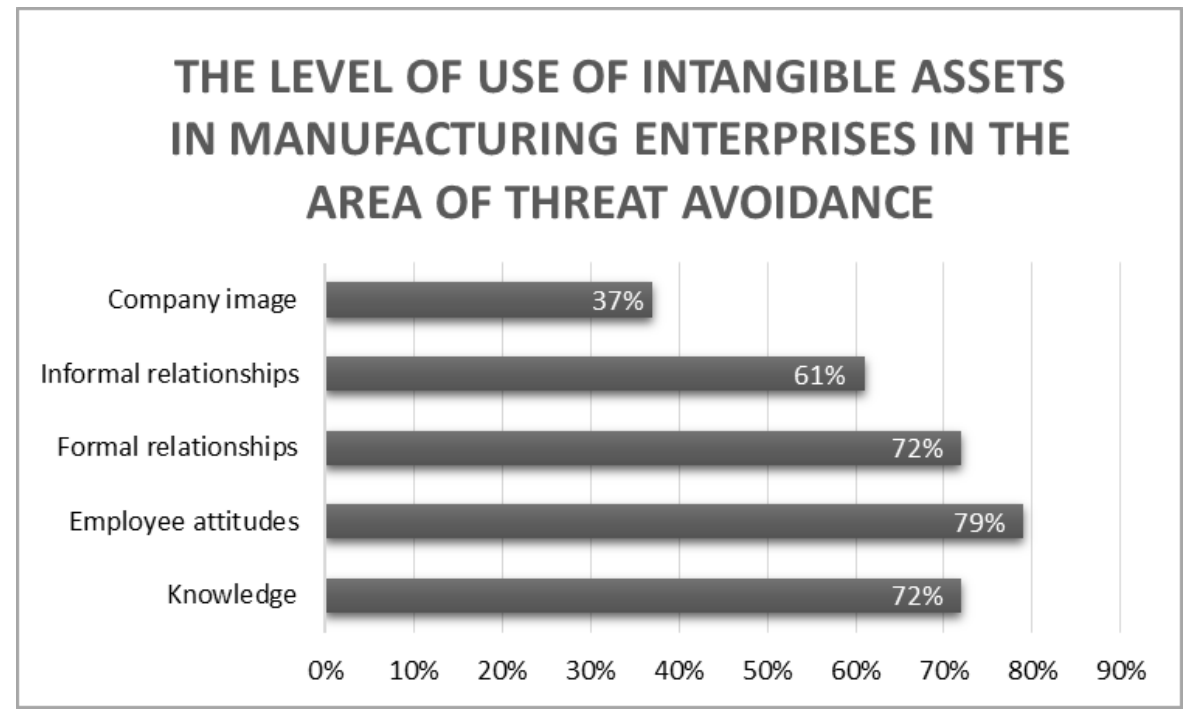

Figure 2. The level of use of intangible assets in manufacturing enterprises in the area of threat avoidance

Source: Own study based on the conducted research

When analyzing the data presented in Figure 2 regarding the use of individual intangible assets, it can be noticed that employee attitudes are used to the highest degree in the area of hazard avoidance. The respondents stated that employee relationships are used up to $79 \%$ of their potential. Similarly, the level of use for knowledge and formal relationships is at the level of $72 \%$. The fourth position is occupied by informal relationships, which are used in $61 \%$. The level of use is the smallest for the image of the company and amounts only to $37 \%$. Such a low level indicates that the respondents do not perceive the image as a useful resource in the area of avoiding threats.

Figure 3 contains data on the use of intangible resources by large and medium enterprises in the manufacturing industry. 


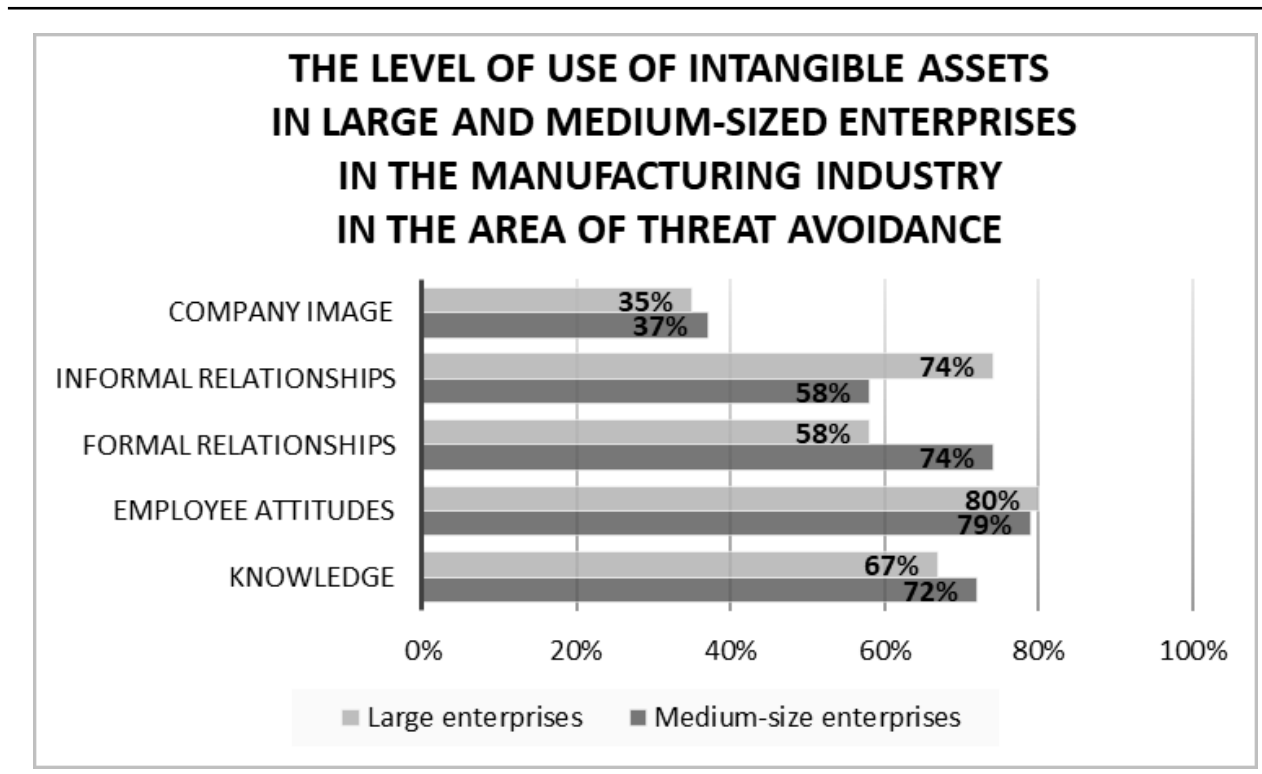

Figure 3. The level of use of intangible assets in large and medium-sized enterprises in the manufacturing industry in the area of threat avoidance

Source: Own study based on the conducted research

In comparison with the collective values (Figure 2), a clear difference can be observed in the use of informal relationships by medium-sized enterprises. It is at the level of $74 \%$ which means that informal relationships take second place immediately after employee attitudes $(80 \%)$ regarding the use of intangible assets by medium-sized companies. Knowledge (67\%) and formal relationships $(58 \%)$ occupy the next positions. The lowest use of the resource goes to the company image $-35 \%$. In large enterprises, also employee attitudes are the most frequently used resource $(79 \%)$. The second place is occupied by formal relationships $(74 \%)$. A similar level of use is presented by knowledge (72\%), and slightly lower by informal relationships (58\%). Similarly, as in the case of medium-sized enterprises, in large organizations, the use of image-related resources is only $37 \%$.

\section{Conclusions}

The results of the study regarding the priority of individual intangible assets in the area of threat avoidance show that, according to the representatives of top management, the most important resource in this behavioral area is employee attitudes. This resource was indicated by almost half of the respondents. Further places were occupied by knowledge and formal and informal relationships with the environment. The company image does not play any important role in this compilation and is used marginally in the area of avoiding threats by enterprises. The analysis of the use of intangible resources proves that employee attitudes 
are used to a significant degree by enterprises, as much as $79 \%$ of potential opportunities. The knowledge resource is equally important and used to a large extent by all enterprises. It is worth noting the difference in the use of formal and informal relationships by medium and large enterprises. For medium-sized entities, relationships with the environment that are not formal are much more important and better used, while for large enterprises formal relationships are more vital. It seems understandable since in large enterprises there are fewer possibilities for informal activities given the complex and extensive organizational structure. In medium-sized enterprises, there is already more flexibility, and in the case of threats, it is possible to use less formal solutions to deal with existing threats.

Summing up, the managers of enterprises in the production industry, regardless of the company's size, should focus on the best use of employee attitudes, because they are the most important intangible assets in the area of avoiding threats.

\section{Literature}

1. Barney J.B. (1991), Firm Resources and Sustained Competitive Advantage, "Journal of Management", Vol. 17, No. 1, p. 99-120.

2. Barney J.B., Ketchen D.J. Jr., Wright M. (2011), The Future of Resource-Based Theory: Revitalization or Decline?, "Journal of Management", Vol. 37, No. 5, p. 1299-1315.

3. Bombiak E. (2017), Kapitat intelektualny jako generator wartości przedsiębiorstwa, [in:] Toruński J., Wyrębek H. (red.), Zarządzanie organizacjami a ryzyko, Wydawnictwo Studio Emka, Warszawa, p. 317-355.

4. Czakon W. (2010), Teoria zasobowa firmy w krzywym zwierciadle, "Przegląd Organizacji", nr 4, p. 8-12.

5. Daroń M. (2017), A Verification of Advantages and Disadvantages in Partnership Relations, "Zeszyty Naukowe Politechniki Częstochowskiej. Zarządzanie", nr 27, t. 1, p. 96-105. DOI: 10.17512/znpcz.2017.3.1.08

6. Głuszek E. (2004), Zarządzanie zasobami niematerialnymi przedsiębiorstwa, Wydawnictwo Akademii Ekonomicznej we Wrocławiu, Wrocław.

7. Jamka B. (2011), Czynnik ludzki we współczesnym przedsiębiorstwie: zasób czy kapitał? Od zarządzania kompetencjami do zarządzania różnorodnościami, Wolters Kluwer, Warszawa.

8. Krupski R. (2012), Badanie znaczenia zasobów niematerialnych $w$ strategii przedsiębiorstwa, [in:] Kaleta A., Moszkowicz K. (red.), Zarzadzanie strategiczne w praktyce $i$ teorii, Wydawnictwo Uniwersytetu Ekonomicznego we Wrocławiu, Prace Naukowe nr 260, Wrocław, p. 238-247.

9. Krupski R., Osyra M. (2013), Użyteczność zasobów niematerialnych w świetle badań empirycznych. Kontekst strategiczny, [in:] Rokita J. (red.), Zarządzanie strategiczne. Modele biznesu. Nowe obszary badań, Górnośląska Wyższa Szkoła Handlowa im. Wojciecha Korfantego, Katowice, p. 15-26.

10. Kuraś M., Łęgowik-Świącik S., Stępień M. (2015), Efektywność zarządzania zasobami niematerialnymi $w$ przedsiębiorstwie inteligentnym, "Zeszyty Naukowe Politechniki Śląskiej. Organizacja i Zarządzanie”, z. 88, p. 183-195.

11. Makowski K. (2000), Kapitat ludzki w skali mikroekonomicznej, [in:] Rybak M. (red.), Zarządzanie kapitałem ludzkim $w$ przedsiębiorstwie, Oficyna Wydawnicza SGH, Warszawa, p. 7-37.

12. Matejun M., Motyka A. (2016), Zasobowe zdolności dynamiczne w zarządzaniu rozwojem firm sektora MSP, Wydawnictwo Politechniki Łódzkiej, Łódź. 
13. Mazur B. (2017), Technology as a Factor of the Development Strategy of Industrial Companies, "Zeszyty Naukowe Politechniki Częstochowskiej. Zarządzanie", nr 27, t. 1, p. 181-191. DOI: 10.17512/znpcz.2017.3.1.13

14. Molloy J., Chadwick C., Ployhart R., Golden S. (2011), Making Intangibles "Tangible": A Multidisciplinary Critique and Validation Framework, "Journal of Management", Vol. 37, No. 5, p. 1496-1518. DOI: 10.1177/0149206310394185

15. Niemczyk J. (2015), Metodologia badań w naukach o zarzadzaniu, [in:] Czakow W. (red.), Podstawy metodologii badań $w$ naukach o zarzadzaniu, Wolters Kluwer, Warszawa, p. $17-25$.

16. Pabian A. (2015), Zrównoważone zarządzanie zasobami ludzkimi - zarys problematyki, "Zeszyty Naukowe Politechniki Częstochowskiej. Zarządzanie”, nr 17, p. 7-16.

17. Potocan V., Szkutnik J., Nedelko Z. (2017), Organization between Environmental and Economic Concern: How Employees' Personal Values and Attitudes Predict Preparedness of Organizations for Environmental Protection, "Zeszyty Naukowe Politechniki Częstochowskiej. Zarządzanie", nr 27, t. 2, p. 96-115. DOI: 10.17512/znpcz.2017.3.2.10

18. Skowron-Grabowska B. (2013), Kreowanie wartości dodanej przedsiębiorstw dla ich klientów i interesariuszy, "Zeszyty Naukowe Politechniki Częstochowskiej. Zarządzanie", nr 12, p. 7-18.

19. Stańczyk-Hugiet E. (2013), Co napędza ewolucję w gospodarce opartej na wiedzy?, "Prace Naukowe Uniwersytetu Ekonomicznego we Wrocławiu”, nr 299, p. 113-121.

20. Zakrzewska-Bielawska A. (2017), Wybory strategiczne $w$ relacyjnej orientacji przedsiębiorstwa, "Handel Wewnętrzny", nr 3(368), p. 181-192.

21. Ziółkowska B. (2012), Podejście zasobowe w strategicznym zarządzaniu wartościa przedsiębiorstwa, "Zeszyty Naukowe Politechniki Częstochowskiej. Zarządzanie”, nr 6, p. 153-159.

\title{
IDENTYFIKACJA I WYKORZYSTANIE ZASOBÓW NIEMATERIALNYCH W ZARZĄDZANIU PRZEDSIĘBIORSTWAMI BRANŻY PRODUKCYJNEJ W OBSZARZE UNIKANIA ZAGROŻEŃ
}

\begin{abstract}
Streszczenie: Celem niniejszego artykułu jest przedstawienie wyników badań dotyczących identyfikacji i wykorzystania pięciu rodzajów zasobów niematerialnych, a mianowicie wiedzy, postaw pracowniczych, relacji sformalizowanych i niesformalizowanych z otoczeniem oraz image'u firmy przez przedsiębiorstwa średniej i dużej wielkości branży produkcyjnej. Badania dotyczą wykorzystania zasobów w jednym z obszarów behawioralnych przedsiębiorstw - unikania zagrożeń.
\end{abstract}

Słowa kluczowe: podejście zasobowe, teoria zasobowa, zasoby niematerialne 